\title{
Johus Hopkins
}

\section{LABOR AND THE MEXICAN REVOLUTION}

\author{
Mexico, 1911-1923 \\ Ramón Eduardo Ruiz
}

Categorizing the Mexican Revolution of 1911 as " no more than a reform movement in the Progressive mold of Woodrow Wilson," Ruiz tries to show how it affected the working class. Most studies treat the Revolution from a political or ideological viewpoint. "I have tried to interpret the Revolution," Ruiz comments, "by looking at what was done to help industrial labor to win wage benefits, sceurity, and above all the right to form and join labor unions. The story presents a shabby picture."

With the fall of the Diaz government in 1911, the Madero regime solicited the support of business rather than that of the workers. The succecding Carranza government, troubled by currency problems before shifting to the gold standard, could not contend with the staggering unemployment figures. The next administration, headed by Obregon, delegated labor responsibilities to state administrations. Revolution, in the Latin American context, Ruiz contends, only strengthens the continuation of political elites and interest groups, it does not bring about real change in political and social conditions.

$$
160 \text { pages } \quad \pm 7 \cdot 35
$$

\section{SQUATTERS AND OLIGARCHS Authoritarian Rule and Policy Change in Peru David Collier}

Changing patterns in authoritarian rule in Latin America have significantly affected economic and social modernization. David Collier explores this relationship in his analysis of Pcru's experience with authoritarian rule between 1948 and 1973 .

From the interviews and archival sources, Collier gives an in-depth profile of the squatter settlements that crowd around Lima. These settlements have generally been viewed by the established classes of Lima as a "belt of misery" and a breeding ground of political radicalism. Collier's findings, however, reveal the covert support of. the Peruvian government for settlement formation. He shows that, in the course of economic and social modernization, there have been four very distinct phases in the relationship between the state and the urban poor. He delineates these phases, contrasting them with the experience of other world regions. His study not only contributes to an understanding of Latin American politics and authoritarianism but also illumines more general sociocconomic problems of urbanization.

$$
192 \text { pages } \quad £ 7.65
$$

THE JOHNS HOPKINS UNIVERSITY PRESS 2.4 Brook St., London W1

L.A.S.-back 


\section{FORTHCOMING TITLES}

\section{THE CHICANO WORKER}

\section{Vernon M. Briggs, Walter Fogel and Fred $\boldsymbol{H}$. Schmidt}

The Chicano Worker is a timely, incisive analysis of the labour market experiences of Mexican-American workers. This is the first study on the subject which makes interpretive use of the 1970 census data on Chicanos, the most current information available. It is also one of the few books concerned exclusively with the economic aspects of Chicano life.

Drawing from census data as well as other sources, The Chicano Worker reports on Chicano employment, labour force participation, occupational and industrial distributions of employment, and various indices of earnings. It also deals with such issues as history, family size, health, and culture.
Texas
156 pp 22 tables
292710402
$£ 7.30$

\section{INEQUALITY IN THE PERUVIAN ANDES}

\section{Class and Ethnicity in Cuzco}

Pierre L. van den Berghe and George P. Primov

Recognising class and ethnicity to be the two most widespread forms of group inequality in large-scale, complex societies, sociologists van den Berghe and Primov undertake an empirical examination of social inequality, focusing on the relationship between these dual bases of social organisation. Their work is the first book-length study of ethnic relations in the Andean area to be published in English.

Unlike conventional treatments of complex societies, this book is neither a community study nor a national-level analysis. Instead it describes a region, the department of Cuzco in the southern Peruvian Andes. Because of the historical importance of the city of Cuzco as capital of the Inca empire and as a major Spanish colonial city, documentation of ethnic and class relations in the region is abundant.
Missouri
$384 p p$
826202136

For further information and catalogues please write to:

Latin American Studies,

American University Publishers Group,

70 Great Russell Street, London WC1B 3BY

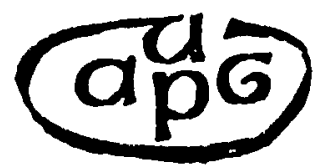

Tel. : $01-4050182$ 


\section{César Vallejo}

The Dialectics of Poetry and Silence

\section{JEAN FRANCO}

This is the first full-length study in English of the poetry of the Peruvian, César Vallejo (1892-1938). A major poet, who approached the problem of revolutionary aesthetics in a manner radically difierent from that of his contemporaries, Vallejo is comparatively little-known outside the Spanish-speaking world.

$£ 11.00$ net

CAMBRIDGE COMMONWEALTH SERIES

\section{The Making of Modern Belize}

Politics, Society and British Colonialism

in Central America

\section{H. GRANT}

This book is the most detailed and comprehensive study of Belizean politics and society yet attempted. Dr Grant, a Guyanese academic and diplomat, examines the processes and institutions which have characterised political change in the country, from its seventeenthcentury origins to the present day.

£14.00 net

\section{CAMBRIDGE LATIN AMERICAN STUDIES 8}

\section{Economic Development of Latin America}

Second Edition: Historical Background and Contemporary Problems

CELSO FURTADO

Translated by SUZETTE MACEDO

A second edition of Professor Furtado's very successful introductory textbook to the economic history and recent development of Latin America. It has been extensively revised and brought up to date.

- Surprisingly successful, eminently readable and a mine of useful information and ideas. ...'

The Economic Journal

Hard covers $\mathbf{1 8 . 8 0}$ net

Paperback $\mathbf{2 . 9 5}$ net

\section{Income Distribution in Latin America}

\section{Edited by ALEJANDRO FOXLEY}

An evaluation of the results of development policies in Latin America over the last ten years. The focus is on the distributional effects of industrial growth on money income and real consumption.

£7.50 net

\section{CAMBRIDGE UNIVERSITY PRESS}




\section{Critical Choices for Americans}

Critical Choices for Americans, a fourteen-volume work on urgent problems that face the United States and the world at the beginning of America's third century, will appear through 1976 and into 1977 under the imprint of Lexington Books.

A wide range of subjects is covered including energy, the environment, and economics; population, food, and land use; raw materials; criminal justice and the law; education; and foreign relations and national defense. A major portion of the work concerns ideas about America, extensive analyses of different regions of the world and the quality of life of communities and individuals.

"The Commission on Critical Choices for Americans, brought together by Neison A Rockefeller in 1973, commissioned 128 of the best minds in the world to highlight alternatives facing America. Their subjects include energy, the environment, population, food, land use. criminal justice, education, defense, and extensive analyses of regions of the world."

About the series in general, TIME Magazine said:

"NEW STARTS FOR AMERICA'S THIRD CENTURY... What emerges from these essays is the sense that in nearly every important field, ideas that dominated for half a century or more are giving way. New notions are being pursued and older ideas, discarded earlier in the 20th century, are being reexamined... Different though the various views of human nature may be, the very use of the term implies that there is something permanent and irreducible in man and that his resistance to outside manipulation is a kind of triumph."

The books are:

Volume I Vital Resources. 288pp. $\$ 14.95$

Volume II The Americans: 1976. 400pp. \$15.95

Volume III How Others See Us. 144pp. \$11.95

Volume IV Power \& Security. 240pp. $\$ 12.95$

Volume V Trade, Inflation \& Ethics. 320pp. \$15.95

Volume VI Values of Growth. 192pp. \$10.95

Volume VII Qualities of Life. 544pp. \$20.95

Volume VIII Western Europe: The Trials of Partnership. 448pp. $\$ 19.95$

Volume IX The Soviet Empire: Expansion \& Detente. 480pp. $\$ 19.95$

Volume X The Middle East: Oil, Conflict \& Hope. 544pp. \$22.95

Volume XI Africa: From Mystery to Maze. 480pp. $\$ 19.95$

Volume XII China \& Japan: A New Balance of Power. 352pp. $\$ 16.95$

Volume XIII Southem Asia: The Politics of Poverty \& Peace. $384 \mathrm{pp}$. $\$ 16.95$

Volume XIV Latin America: Struggle for Progress. 224pp. $\$ 13.95$

\section{Special Series Price- $\mathbf{\$ 2 0 0 . 0 0}$}

For additional information, please contact:

Lexington Books, 125 Spring Street, Lexington, Massachusetts 02173, or call (617) 862.6650 or (212) $924-6460$. 


\section{FORO INTERNACIONAL}

Revista Trimestral Publicada por El Colegio de México

Fundador: DANIEL COSIO VILLEGAS

Director: RAFAEL SEGOVIA

Director Adjunto: BLANCA TORRES RAMIREZ

VOL. XVII OCTUBRE-DICIEMBRE, $1976 \quad$ NUM. 2

\section{ARTICULOS}

I N D I C E

David Ibarra, Reflexiones sobre la empresa pública en México

Francisco Alba Hernández, Exodo silencioso: la emigración de trabajadores mexicanos a Estados Unidos

Soledad Loaeza, Henry Kissinger: de la amenaza como instrumento para la paz.

Herman Rosenkranz y Benny Pollack, Estrategias politicas divergentes, movilización convergente y sectores medios: la izquierda y la Democracia Cristiana en Chile, 1963-1973

Edy Kaufman, La politica exterior de la Unidad Popular chilena

Joel G. Verner, Los abogados en la Cámara de Diputados de Brasi!

\section{RESENAS DE LIBROS}

\section{I_IBROS RECIBIDOS}

Precio del ejemplar

30.00 pesos, U.S. Dls. 2.50

Suscripción anual (4 numeros) 100.00 pesos, U.S. Dls. 8.50

\section{EL COLEGIO DE MEXICO}

Departamento de Publicaciones

Camino al Ajusco 20

México 20, D.F. 


\section{REVISTA DEL CENTRO DE ESTUDIOS EDUCATIVOS}

Volumen VI

Cuarto trimestre de 1976

Número 4

ARTICULOS

Planeación y reforma de la educación superior en México, 19701976. Jean Pierre Vielle.

Financiamiento de la educación y distribución del ingreso. JeanPierre Jallade.

Elaboración de un instrumento para detectar alumnos con problemas de conducta escolar. Araceli Otero.

\section{INFORMES, NOTAS Y DOCUMENTOS}

Financiamiento de la educación privada en América Latina. (/nforme sobre la situación en Bolivia, Colombia, México, Perí y Venezuela.) Carlos Muñoz Izquierdo y Alberto Hernández Medina.

Televisión educativa y empleo de los medios masivos para la celucación en Cuba. Jorge Werthein.

Los museos escolares del INAH (Un intento de innovación educativa en México). Guillermo de la Peña, Agustín Escobar y Humberto González Ch.

Reunión latinoamericana y del Caribe sobre nuevas formas de educación post-secundaria. Pablo Latapi Sarre.

\section{ESTADISTICA}

Gasto educativo, costo unitario y pirámide escolar en Méxicu, 1974-75. Pedro Gerardo Rodríguez.

Indice del año 1976.

\section{PRECIOS DE SUSCRIPCION}

Para Mexico: $\$ 150.00$ m.n. ( $\$ 120.00$ para estudiantes y maestros). PARA OTROS PAISES, correo ordinario: 12 dls. (registrado y conacuse de recibo); correo aéreo: Centro y Sud América, 16 dls.; USA y Canadá, 19 U.S. dls.; otros países, 22 dls. (registrado, con acuse de recibo y por entrega inmediata).

Suscripción y pedidos a:

REVISTA DEL CENTRO DE ESTUDIOS EDUCATIVOS Av. Revolución 129] México 20, D.F. Tel. 593-59-77 


\title{
Farmers in Revolt \\ The Revolutions of 1893 in the Province of Santa Fe, Argentina
}

\author{
EZEQUIEL GALLO
}

Dr Gallo describes the expansion of the agricultural frontier in Santa Fe and the way in which the region became a primary centre of rapid economic development. His analysis of the consequent social and political changes in the province and more detailed study of the 1893 revolts throws new light on more general phenomena-the assimilation and political participation of immigrants, the formation of the Radical Party, the functioning of the Argentine political system and the characteristics of rural populism. Based on a wide range of manuscript and newspaper sources. the book is an important contribution to modern Argentine history.

Institure of Latin American Studies Monograph, No. 7

$£ 4.00$

\section{The Athlone Press UNIVERSITY OF LONDON}

\section{SLAVERY ON THE SPANISH FRONTIER}

\section{The Colombian Chocó 1680-1810}

By Willian Frederick Sharp

The Chocó. now an intendancy of Colombia, was one of the few tropical mining regions in the New World where Spaniards subjected both blacks they brought with them and Indians to slavery. The conquerors, who came to the region to mine its gold and platinum, had no interest in establishing permanent settlements and little concern for the welfare of the slaves except as producers of wealth.

The people of the Chocó today are descendants of those diverse groups. Despite its continued mineral wealth, the region remains underdeveloped today, its inhabitants subsisting at various levels of poverty. In this carefully documented account Sharp depicts frontier life in the Choco, its economic achievements and failures, its effect on the culture of the people brought together there. He effectively demonstrates that the poverty of the region has its roots in a self-serving domination by conquerors impelled by greed and devoid of vision. 350 pages. \$9.95.

\section{University of Oklahoma Press}

1005 Asp Avenue

Norman, Oklahoma 73109 
Journal of Latin American Studies is published twice a year under the academic sponsorship of the Centres or Institutes of Latin American Studies at the Universities of Cambridge, Glasgow, Liverpool, London and Oxford.

The scope of the journal is the study of Latin America from the standpoint of the social sciences, including anthropology, archaeology, economics, geography, history, international relations, politics, sociology, etc., though it is not concerned with linguistic or literary studies.

Editorial policy avoids commitment to any political viewpoint or ideology, but welcomes free discussion of such issues in the Latin American context, on the understanding that all responsibility for opinions expressed rests exclusively with the author concerned and not with either the journal or its editors.

Contributions are invited from all parts of the world. Articles should generally not be more than 8,000 words long, and two copies, typed with double-spacing, should be submitted. Diagrams and maps may be included by arrangement with the editors. The journal is published in English, but articles written in other languages may be considered, and arrangements made as required for translation into English. Contributors should keep one copy of the typescript for use in correcting proofs.

All contributions and editorial correspondence should be addressed to Journal of Latin American Studies, Institute of Latin American Studies, 31 Tavistock Square, London, WCiH $9 \mathrm{HA}$.

Each contributor will receive, free of charge, 25 offprints of their article and a copy of the issue of the journal in which it appears.

\section{CONTRIBUTORS TO THIS ISSUE}

Dr A. J. R. Russell-Wood is a Professor of History at the Johns Hopkins University.

DR W. M. Mathew is a Lecturer in the Department of Social Studies at the University of East Anglia.

Dr Roger Gravil is Senior Lecturer in Latin American History at the University of Zambia.

Dr Michael J. Francis is Associate Professor in the Department of Government and International Studies at the University of Notre Dame.

Dr Michael Kryzaner is Associate Professor in the Department of Political Science at Bridgewater State College, Mass. 
J. Lat. Amer. Stud.

\section{Journal of \\ Latin American Studies}

Volume 9 Part I May 1977

\section{A R T I C LES}

A. J. R. RusselL-Wood: Women and Society in Colonial Brazil I-34

W. M. Mathew : A Primitive Export Sector: Guano Production in Mid-Nineteenth-Century Peru

Roger Gravil: The Anglo-Argentine Connection and the War of $1914-1918$

Michael J. Francis: The United States and Chile during the Second World War: the Diplomacy of Misunderstanding

Michael J. Kryzanek: Political Party Decline and the Failure of Liberal Democracy: the PRD in Dominican Politics

\section{REVIEWS by}

Elisabeth Long, I45-I47; Bernard Naylor, I47-I48; Warwick Bray, I49, 152-153; Carl N. Degler, 150-152; John Lynch, 153-154, I6I-162; Michael P. Costeloe, 154-156; David Brading, 156-159; Brian Hamnett, 159-16r; Simon Collier, I62-163; Cristóbal Kay, I64-165; J. Colin Crossley, I66-167; James R. Scobie, 167-170; Ian Roxborough, I70-171; David Skidmore, I72-173; Bryan R. Roberts, I73-175; Thomas Schoonover, 175-176; M. H. J. Finch, 176-177; Christopher Abel, 177-178; R. F. Colson, I78-I79; Warren Schapiro, I79-18I; R. J. Bromley, I8II83; David A. Preston, I83-184; Michael Redclift, 184-186.

\section{BOOK NOTICES by}

Warwick Bray, 187; Henry Kamen, 187-188; Francis Lambert, 188-189; Alan Gilbert, 189-190; Peter Calvert, 190; John Fisher, 19I; George Bankes, 192.

(C) Cambridge University Press 1977 .

CAMBRIDGE UNIVERSITY PRESS

Bentley House, 200 Euston Road, London NWI 2DB

32 East 57th Street, New York, N.Y. 10022

Printed in Great Britain by The Eastern Press Ltd., London and Reading 